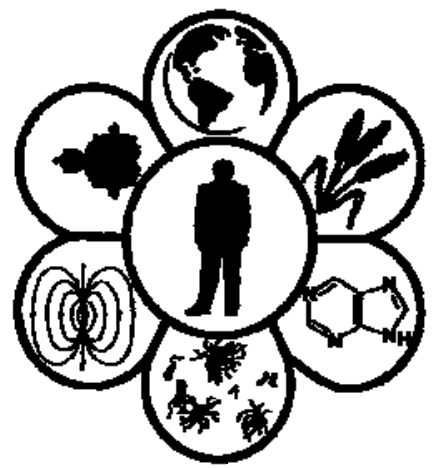

Вісник Дніпропетровського університету. Біологія. Медицина Vìsnik Dnìpropetrovs'kogo unìversitetu. Serìa Bìologîa, medicina

Visnyk of Dnipropetrovsk University. Biology, medicine. 2013. 4(1)

ISSN 2310-4155

www.medicine.dp.ua

УДК 575.155:616.697

\title{
Хромосомні аномалії у чоловіків із різним ступенем порушення сперматогенезу
}

\author{
Л.Я. Пилип ${ }^{1}$, Л.О. Спіненко ${ }^{1}$, В.Д. Зукін ${ }^{1}$, Н.М. Білько ${ }^{2}$ \\ ${ }^{1}$ Клініка репродуктивної медичини «Надія», Київ, Украӥна \\ ${ }^{2}$ Центр молекулярних та клітинних досліджень \\ Національного університету «Києво-Могилянська академія», Київ, Украӥна
}

\begin{abstract}
Проведено аналіз частот і типів хромосомних аномалій у 724 чоловіків із безпліддям. Аномалії каріотипу виявлено у 48 (6,6\%) пацієнтів. Аномалії аутосом склали $67 \%$, гоносом - 33\%. Аномалії аутосом представлено структурними перебудовами. Реципрокні транслокації виявлено у 19 пацієнтів (2,6\%), робертсонівські транслокації - у 9 (1,2\%), інверсії - у 4 (0,6\%). Аномалії гоносом включали 14 випадків анеуплоїдії статевих хромосом та 2 випадки термінальної делеції хромосоми Ү. Синдром Клайнфельтера виявлено у $67 \%$ пацієнтів з азооспермією. Зареєстровано достовірне підвищення частоти кількісних хромосомних аномалій у групі пацієнтів з азооспермією $(P<0,001)$. Різниці у частотах структурних аномалій у підгрупах пацієнтів не виявлено. Зареєстровано підвищення частоти хромосомних аномалій у підгрупах пацієнтів зі зниженням концентрації сперматозоїдів. Хромосомні аномалії виявлено з частотою $1,1 \%$ у пацієнтів із нормозооспермією, 4,3\% - у пацієнтів з астенозооспермією, 6,5\% - у пацієнтів 3 олігоастенозооспермією, 11,6\% - у пацієнтів з олігоастенотератозооспермією та 35,0\% - у пацієнтів з азооспермією. Виявлено достовірне підвищення частоти хромосомних аномалій у пацієнтів з азооспермією $(P<0,001)$ та олігозооспермією $(P<0,001)$, порівняно 3 чоловіками без відхилень показників спермограми. Отримані результати розглянуто в контексті їх застосування для визначення групи пацієнтів, дослідження каріотипу яких необхідне перед проведенням циклів допоміжних репродуктивних технологій.
\end{abstract}

Ключові слова: хромосомні аномалії; безпліддя; каріотип; азооспермія; олігозооспермія

\section{Chromosomal abnormalities in patients with sperm disorders}

\author{
L.Y. Pylyp ${ }^{1}$, L.A. Spinenko ${ }^{1}$, V.D. Zukin ${ }^{1}$, N.M. Bilko ${ }^{2}$ \\ ${ }^{1}$ Clinic of Reproductive Medicine "Nadiia", Kyiv, Ukraine \\ ${ }^{2}$ Centre of Molecular and Cell Research, National University of "Kyiv-Mohyla Academy", Kyiv, Ukraine
}

\begin{abstract}
Chromosomal abnormalities are among the most common genetic causes of spermatogenic disruptions. Carriers of chromosomal abnormalities are at increased risk of infertility, miscarriage or birth of a child with unbalanced karyotype due to the production of unbalanced gametes. The natural selection against chromosomally abnormal sperm usually prevents fertilization with sperm barring in cases of serious chromosomal abnormalities. However, assisted reproductive technologies in general and intracytoplasmic sperm injection in particular, enable the transmission of chromosomal abnormalities to the progeny. Therefore, cytogenetic studies are important in patients with male factor infertility before assisted reproduction treatment. The purpose of the current study was to investigate the types and frequencies of chromosomal abnormalities in 724 patients with infertility and to estimate the risk of chromosomal abnormalities detection in subgroups of patients depending on the severity of spermatogenic disruption, aiming at identifying groups of patients in need of cytogenetic studies. Karyotype analysis was performed in 724 blood samples of men attending infertility clinic. Chromosomal preparation was performed by standard techniques. At least 20 GTG-banded metaphase plates with the resolution from 450 to 750 bands per haploid set were analysed in each case.
\end{abstract}

${ }^{1}$ Клініка репродуктивної медицини «Надія», вул. М. Кривоноса, 19а, м. Київ, 03037, Украӥна.

Тел.: +38044-537-75-97, факс:+38044-537-75-99.E-mail: l.pylyp@ivf.com.ua, l.emelyanenko@ivf.com.ua,v.zukin@ivf.com.ua ${ }^{2}$ Національний університет «Києво-Могилянська академія», вул. Г. Сковороди, 2, м. Київ, 04655, Украйна.

Тел./факс: +38044-425-60-57. E-mail: nbilko@ukma.kiev.ua

${ }^{1}$ Clinic of Reproductive Medicine "Nadiya", Kyiv, Ukraine, vul. M. Kryvonosa, 19a, Kyiv, 03037, Ukraine.

Tel.: +38044-537-75-97,Fax:+38044-537-75-99.E-mail: l.pylyp@ivf.com.ua, l.emelyanenko@ivf.com.ua, v.zukin@ivf.com.ua

${ }^{2}$ National University of "Kyiv-Mohyla Academy", vul. G. Skovorody, Kyiv, 04655, Ukraine.

Tel./Fax: +38044-425-60-57.E-mail: nbilko@ukma.kiev.ua

(С Л.Я. Пилип, Л.О. Спіненко, В.Д. Зукін, Н.М. Білько, 2013 
When chromosomal mosaicism was suspected, this number was increased to 50. Abnormal karyotypes were observed in 48 (6.6\%) patients, including $67 \%$ of autosomal abnormalities and $33 \%$ of gonosomal abnormalities. Autosomal abnormalities were represented by structural rearrangements. Reciprocal translocations were the most common type of structural chromosomal abnormalities in the studied group, detected with the frequency of $2.6 \%(n=19)$, followed by Robertsonian translocation, observed with the frequency of $1.2 \%(n=9)$. The frequency of inversions was $0.6 \%(n=4)$. Gonosomal abnormalities included 14 cases of sex chromosome aneuploidy and 2 cases of terminal deletion of $\mathrm{Y}$ chromosome. Klinefelter syndrome was detected in $67 \%$ of patients with azoospermia. A significant increase in the frequency of numerical chromosomal abnormalities was observed in a group of patients with azoospermia $(P<0.001)$. No differences were detected in the frequency of structural abnormalities in subgroups of patients. An increase in the frequency of chromosomal abnormalities with the decrease of sperm count was observed. Chromosomal abnormalities were detected with frequency $1.1 \%$ in a group of patients with normospermia, $1.9 \%$ in a group of patients with asthenozoospermia, $4.3 \%$ in patients with asthenoteratozoospermia, $6.5 \%$ in patients with oligoasthenozoospermia, $11.6 \%$ in patients with oligoasthenoteratozoospermia and $35 \%$ in a group of patients with azoospermia. Significant increase of the prevalence of chromosomal abnormalities was detected in subgroups of patients with azoospermia $(P<0.001)$ and oligozoospermia $(P=0.001)$ as compared to patients with normozoospermia. These results are considered to be criteria for selection of patients in need of cytogenetic studies before in vitro fertilization cycles because of the highest risk of chromosomal abnormalities detection.

Keywords: chromosomal abnormalities; infertility; karyotype; azoospermia; oligozoospermia

\section{Вступ}

Репродуктивні проблеми виникають у $15 \%$ подружніх пар (deKrester, 1997). Приблизно у половині випадків причина безпліддя полягає у чоловічому факторі. У $30 \%$ пацієнтів після обстеження не вдається з'ясувати етіологію безпліддя та чоловіче безпліддя визначають як ідіопатичне. Значна варіабельність порушень сперматогенезу у пацієнтів із безпліддям, а також різниця протоколів обстеження у репродуктивних клініках унеможливлюють чітке визначення ідіопатичного безпліддя. Ймовірно, у більшості випадків ідіопатичного безпліддя етіологічним чинником $є$ генетичні порушення (Huynch et al., 2002). Хромосомні аномалії можуть бути однією $з$ причин порушення сперматогенезу у пацієнтів із безпліддям (Harton and Tempest, 2012; Giwersman, 2012). Серед хромосомних аномалій виявляють зміни кількості статевих хромосом і структурні перебудови аутосом (реципрокні, робертсонівські транслокації, інверсії, інсерції, маркерні хромосоми), частота яких залежить від особливостей досліджуваної групи (Martin, 2008; O'FlynnO'Brien et al., 2010; Wang et al., 2010; Yatsenko et al., 2010; Dul et al., 2012). Через високу ймовірність утворення незбалансованих гамет у носіїв хромосомних аномалій підвищується ризик невиношування та народження дітей із хромосомною патологією (Stephenson and Sierra, 2006). У нормі гамети із хромосомними аномаліями мають низький потенціал до запліднення.

Природна селекція сперматозоїдів із нормальним хромосомним набором, як правило, запобігає утворенню зигот із хромосомними аномаліями. Однак допоміжні репродуктивні технології (ДРТ), зокрема інтрацитоплазматична ін'єкція сперматозоїда (ICSI), забезпечують подолання даного ефективного природного бар'єру i, як наслідок, уможливлюють передачу хромосомної патології нащадкам, що підвищує ризик виникнення в них аномалій генетичної природи (Georgiou et al., 2006; Lipshultz and Lamb, 2007). Тому перед використанням ДРТ рекомендовано дослідження каріотипу чоловіків із відхиленнями показників спермограми. Однак рекомендації щодо каріотипування відрізняються у різних країнах та не завжди збігаються з практикою. Зокрема, Американська асоціація репродуктивної медицини рекомендує проведення цитогенетичного дослідження у пацієнтів iз необструктивною азооспермією та тяжкою олігозооспермією (концентрація сперматозоїдів $<5-10 \times 10^{6}$ мл $^{-1}$ ) до проведення ICSI (ASRM, 2006). Британський національний інститут здоров'я та якості медичної допомоги рекомендує досліджувати каріотип перед ICSI у пацієнтів із «тяжким дефіцитом сперматозоїдів» без чіткого визначення даного поняття (NICE, 2004). Враховуючи розбіжності у рекомендаціях щодо каріотипування пацієнтів перед ICSI, метою даної роботи було оцінити частоту виявлення хромосомних аномалій у пацієнтів із різним ступенем тяжкості порушень сперматогенезу та визначити групу пацієнтів із найвищим ризиком хромосомних аномалій, дослідження каріотипу яких $є$ найдоцільнішим перед проведенням циклів ДРТ.

\section{Матеріал і методи досліджень}

Проведено цитогенетичне дослідження лімфоцитів периферичної крові 724 чоловіків, що проходили первинне обстеження у зв'язку з безпліддям у Клініці репродуктивної медицини «Надія» із січня 2009 по серпень 2012 року. Середній вік пацієнтів становив 35,2 \pm 6,0 років. Хромосомними аномаліями вважали кількісні та структурні перебудови хромосом; поліморфні варіанти розглядали як варіант норми. Цитогенетичний аналіз проводили на GTG-фарбованих метафазних пластинах лімфоцитів периферичної крові з роздільною здатністю 550 та більше дисків на гаплоїдний геном відповідно до Міжнародної номенклатури хромосом людини (ISCN 2009). У кожному випадку аналізували 20 метафазних пластин; при підозрі на мозаїцизм кількість проаналізованих пластин збільшували до 50.

Оцінку еякуляту проводили згідно із критеріями Всесвітньої організації охорони здоров'я (WHO, 2010). Висновок «олігозооспермія» ставили при концентрації сперматозоїдів нижчій, ніж $15 \times 10^{6}$ мл $^{-1}$; морфологічні особливості оцінювали за Kruger et al. (1986). Для порівняння частот хромосомних аномалій у підгрупах пацієнтів використовували критерій $\chi^{2}$. Для оцінки ризиків застосовували показник співвідношення ризиків OR (odd sratio).

\section{Результати та їх обговорення}

Частота хромосомних аномалій у досліджуваній групі пацієнтів склала 6,6\% (табл. 1). Аномалії аутосом виявлено у $67 \%(n=32)$ випадків, гоносом - у $33 \%(n=16)$ пацієнтів. Аномалії гоносом - найчастіша хромосомна патологія пацієнтів із тяжким порушенням сперматоге- 
незу. Пацієнти з аномаліями гоносом, як правило, характеризуються азооспермією. Аномалії статевих хромосом зареєстровано у 16 пацієнтів: дисомію хромосоми $\mathrm{Y}$ (каріотип 47, XYY) виявлено у двох випадках (одну повну та одну мозаїчну); ще у двох пацієнтів зареєстровано термінальну делецію хромосоми Yq11.2-qter, що включає локус, який кодує гени сперматогенезу (Reynolds and Cook, 2005; Giwersman et al., 2012), у дев'яти чоловіків виявлено повну дисомію хромосоми $\mathrm{X}$ (каріотип 47, XXY, синдром Клайнфельтера), мозаїчну форму - у трьох пацієнтів.

Частота окремих типів хромосомних аномалій у пацієнтів із безпліддям

\begin{tabular}{|c|c|c|}
\hline Тип аномалії & $\begin{array}{l}\text { Кількість } \\
\text { пацієнтів }\end{array}$ & Частота, \% \\
\hline Реципрокні транслокації & 19 & 2,6 \\
\hline Анеуплоїдії статевих хромосом & 14 & 1,9 \\
\hline Робертсонівські транслокації & 9 & 1,2 \\
\hline Термінальні делеції хромосоми Y & 2 & 0,3 \\
\hline Інверсії & 4 & 0,6 \\
\hline Разом & 48 & 6,6 \\
\hline
\end{tabular}

Синдром Клайнфельтера - найчастіша аномалія гоносом, яку виявляють у пацієнтів із безпліддям. Ії частота складає $0,1-0,2 \%$ серед новонароджених і зростає до 0,5\% у пацієнтів з олігозооспермією та $11-23 \%$ у пацієнтів з азооспермією (Nielsen and Wohlert, 1991; Kleiman et al., 1996; Huynh et al., 2002). Синдром Клайнфельтера становить 67\% аномалій каріотипу у пацієнтів з азооспермією та 19\% - у пацієнтів з олігозооспермією (Mau-Holzmann, 2005); у досліджуваній групі - 75\% та 15\% відповідно. Приблизно у 80\% випадків синдрому Клайнфельтера виявляють немозаїчний каріотип 47, $\mathrm{XXY}$ (рис. 1), фенотипічним проявом якого $є$ азооспермія (Lanfranco et al., 2004).

У 20\% пацієнтів із синдромом Клайнфельтера виявляють мозаїчний каріотип, найчастіше - 47, XXY / 46, $\mathrm{XY}$. Мозаїчний каріотип легко діагностувати за наявності в лімфоцитах пацієнтів декількох клітинних ліній, однак неможливо виключити гонадний мозаїцизм за наявності немозаїчного каріотипу крові, що ускладнює медико-генетичне консультування таких пацієнтів. Наявність мозаїчного каріотипу з нормальним клоном клітин є прогностично сприятливішою, оскільки, як правило, не спричинює азооспермію, а зумовлює менші порушення сперматогенезу (Maiburg et al., 2012; Oates, 2012). У досліджуваній групі всі три пацієнти 3 мозаїчним синдромом Клайнфельтера характеризувались не повною відсутністю сперматозоїдів в еякуляті, а олігоастенозооспермією з концентрацією сперматозоїдів, що не перевищувала $5 \times 10^{6}$ мл $^{-1}$. Більше того, імовірність виявлення сперматозоїдів у матеріалі тестикулярної біопсії у пацієнтів із мозаїчним каріотипом і азооспермією значно вища. За літературними даними (Schiff et al., 2005), у половині випадків тестикулярної біопсії у пацієнтів із синдромом Клайнфельтера вдається отримати сперматозоїди. Використання ICSI у таких пацієнтів підвищує ризик передачі хромосомних аномалій потомству.

У низці досліджень виявлено здатність чоловічих гермінальних клітин із набором XXY проходити мейоз i утворювати гіпергаплоїдні гамети XX та XY (Huynch et al., 2002). Однак у більшості робіт із використанням флуоресцентної гібридизації in situ (FISH) на деконденсованих ядрах сперматозоїдів пацієнтів із синдромом Клайнфельтера виявлено значно нижчі частоти сперматозоїдів із дисоміями статевих хромосом, ніж теоретично очікувані $50 \%$ (Ferlin et al., 2005). Ймовірно, XXY клітини не здатні проходити мейоз, а сперматозоїди пацієнтів із синдромом Клайнфельтера походять від гермінальних клітин із нормальним каріотипом. Наявність сперматозоїдів із дисоміями статевих хромосом - результат порушення сегрегації хромосом гермінальних клітин із нормальним каріотипом через несприятливий вплив мікрооточення, як показано для мишей із набором статевих хромосом XXY (Mroz et al., 1999). Крім підвищення частоти нерозходження статевих хромосом у пацієнтів із синдромом Клайнфельтера існує ризик підвищення частоти нерозходження аутосом, зокрема хромосоми 21 (Lanfranco et al., 2004). Тому пацієнтам із синдромом Клайнфельтера у циклах ДРТ без донації сперми рекомендовано проведення передімплантаційної генетичної діагностики (ПГД).

Другою за частотою кількісною аномалією гоносом у досліджуваній групі пацієнтів була дисомія хромосоми Y - каріотип 47, XYY. Більшість пацієнтів із каріотипом 47, XYY не мають зниження фертильності, однак частота даної аномалії у групі пацієнтів із репродуктивними розладами підвищена удвічі - втричі порівняно із загальнопопуляційною (0,2-0,3\% порівняно з 0,05\% у новонароджених) (Yoshida et al., 1997). Частота дисомії Y $(47$, XYY) у досліджуваній групі становила 0,27\%. Зміни у показниках спермограми таких пацієнтів різняться від нормозооспермії до тяжкої олігозооспермії. Така варіабельність порушень сперматогенезу зумовлена різницею у частотах мейотичних конфігурацій додаткової хромосоми Y з іншими статевими хромосомами, оскільки деякі з можливих конфігурацій можуть блокувати мейоз та порушувати сперматогенез (Blanco et al., 2001).

Серед аномалій аутосом у пацієнтів із безпліддям найчастіше виявляють структурні перебудови. У досліджуваній групі зареєстровано 19 реципрокних і 9 робертсонівських транслокацій, а також 4 інверсії. Робертсонівські транслокації виникають у результаті центромерного злиття довгих плечей акроцентричних хромосом 13, 14, 15, 21, 22. Утрата коротких плечей акроцентричних хромосом не має фенотипічного прояву, оскільки гени, локалізовані в їх районах, високоповторювані та закодовані в коротких плечах інших акроцентричних хромосом. Тому каріотип носіїв робертсонівських транслокацій залишається збалансованим. Із можливих комбінацій 5 акроцентричних хромосом, найчастіше виявляють транслокації із залученням хромосом 13/14 та $14 / 21$ - $\operatorname{der}(13 ; 14)$ та $\operatorname{der}(14 ; 21)$. Iз 9 робертсонівських транслокацій, зареєстрованих у досліджуваній групі, у $78 \%(n=7)$ випадків виявляли $\operatorname{der}(13 ; 14)$ (рис. 2).

Частота робертсонівських транслокацій становить 0,001\% у новонароджених (Nielsen and Wohlert, 1991), 0,2\% - у пацієнтів 3 азооспермією та 1,5\% - у пацієнтів 3 олігозооспермією. За даними Ravel et al. (2006), частота $\operatorname{der}(13 ; 14)$ у донорів сперми 3 нормальними показниками еякуляту не відрізняється від частоти даної перебудови у групі новонароджених. Тобто у носіїв робертсонівських транслокацій не обов'язково розвиваються порушення сперматогенезу та не всі вони мають репродуктивні проблеми. 

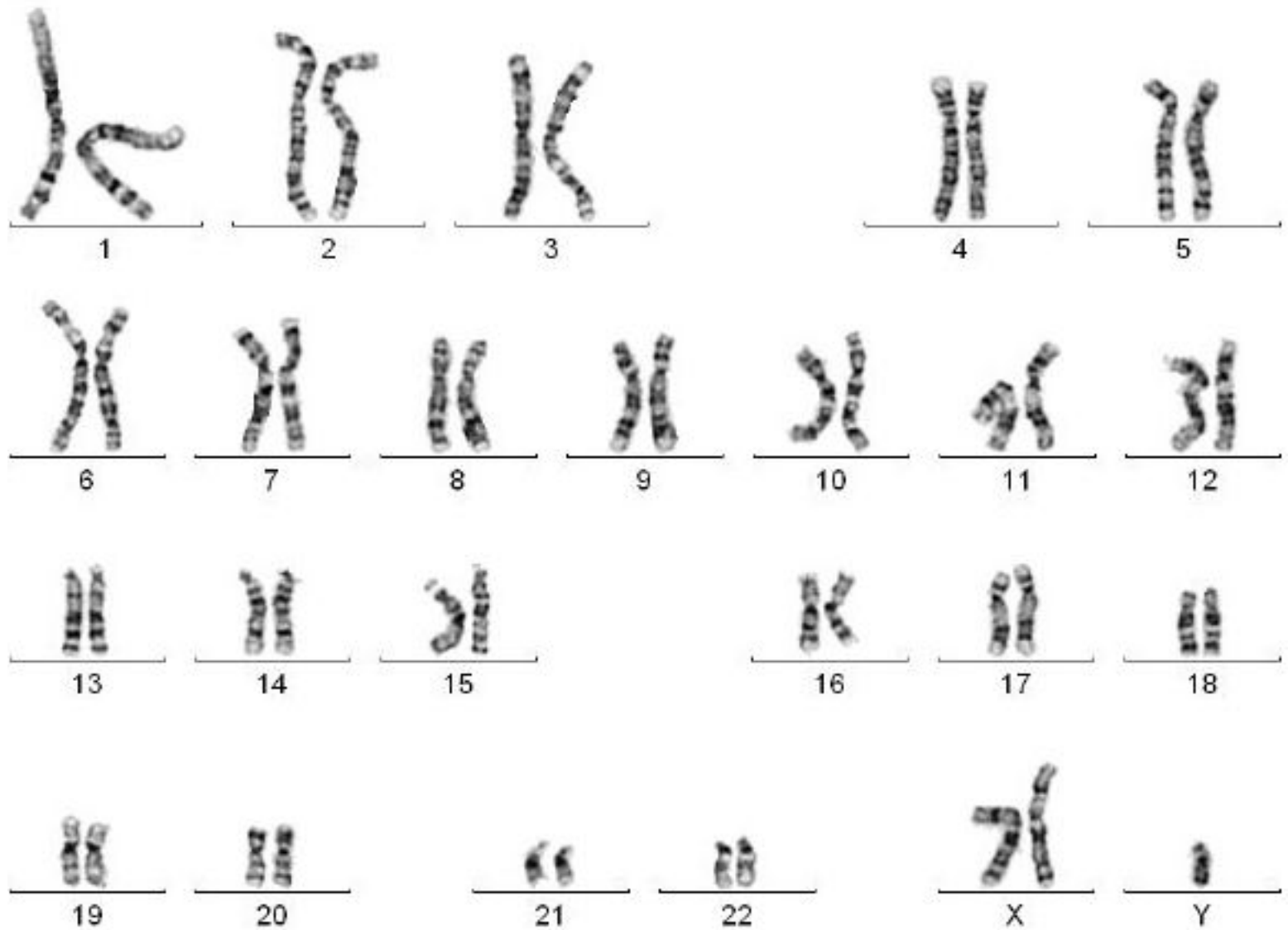

Рис. 1. Каріотип паціснта із синдромом Клайнфельтера
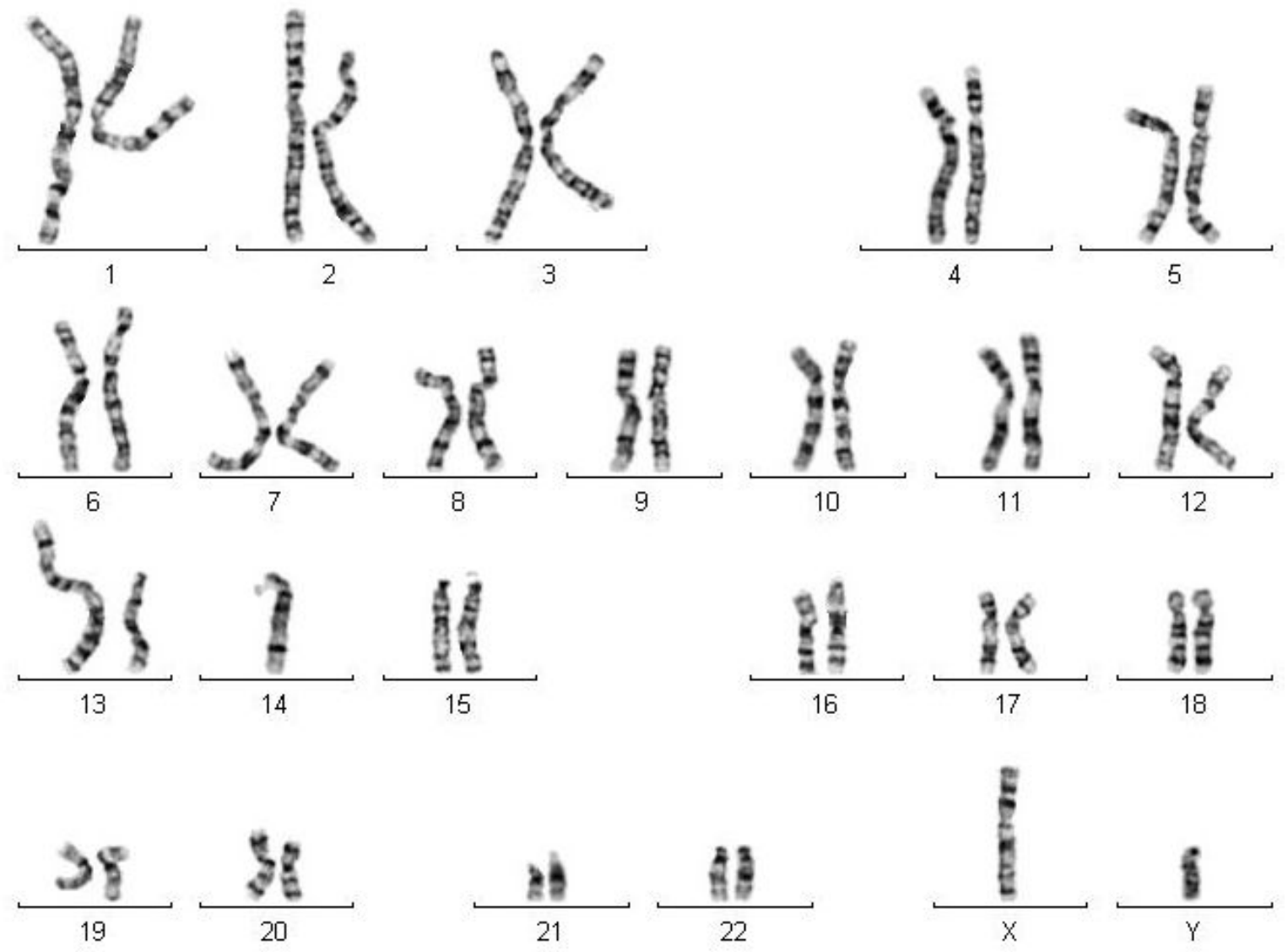

Рис. 2. Каріотип пацієнта з робертсонівською транслокацісю - 45, XY, $\operatorname{der}(13 ; 14)(q 10 ; q 10)$ 
Однак у дослідженій групі в усіх гетерозиготних носіїв робертсонівських транслокацій виявлено відхилення показників спермограми: у 2 (22\%) пацієнтів зареєстровано азооспермію, у 2 (22\%) олігоастенозооспермію, ще у 2 (22\%) олігоастенотератозооспермію, та у 3 (34\%) астенотератозооспермію. Механізм, за яким, імовірно, робертсонівські транслокації зумовлюють порушення сперматогенезу, полягає у блоку мейозу частини гамет із хромосомними аномаліями. Транслоковані хромосоми у мейозі утворюють триваленти, тип анафазного розходження яких зумовлює утворення збалансованих або незбалансованих (із трисоміями та моносоміями) гамет. Частина гамет із незбалансованим каріотипом елімінується під час дозрівання сперматозоїдів, наприклад, через апоптичний шлях, як це показано для мишей-носіїв робертсонівських транслокацій (Eaker et al., 2001), у peзультаті чого знижуються показники концентрації сперматозоїдів.

У досліджуваній групі пацієнтів реципрокні транслокації виявлено з частотою 2,6\%. Реципрокні транслокації виникають у результаті обміну ділянками між хромосомами без змін кількості генетичного матеріалу (рис. 3). Реципрокні транслокації виявлено у 19 пацієнтів із порушенням сперматогенезу від азооспермії до астенозооспермії. Наявність збалансованих транслокацій може мати фенотипічний прояв від астенозооспермії до олігоастенотератозооспермії, рідше викликаючи азооспермію (табл. 2). У пацієнтів з азооспермією транслокації становили лише $25 \%(n=3)$ усієї патології, з олігоастено- та олігоастенотератозооспермією - 80\% $(n=4)$ та $70 \%(n=$ 7), відповідно. У пацієнтів з астенотератозооспермією транслокації були єдиним типом хромосомних аномалій.

Як правило, реципрокні транслокації унікальні, тобто виникають через утворення випадкових точок розриву та сполучення у залучених хромосомах. У досліджуваній групі не виявлено жодної реципрокної транслокації між хромосомами 4, 10, 11, 13, 20, 21. Решта хромосом були залучені до перебудов із випадковими точками розриву та сполучення.

Репродуктивні ризики для носіїв транслокації зумовлені утворенням незбалансованих гамет із частковими трисоміями та моносоміями за районами хромосом, що залучені до перебудови. Частота незбалансованих гамет може коливатись від 19 до 81\%, залежно від типу транслокації, хромосом і районів, включених до перебудови (Escudero et al., 2003; Anton et al., 2007). Тому носіям транслокації показано проведення циклів ДРТ із ПГД для зниження ризику невиношування та народження дитини з незбалансованим хромосомним набором.

Інверсії аутосом - другий за частотою тип структурних перебудов після транслокацій. Інверсії хромосом структурні перебудови, що утворюються у результаті виникнення двох точок розриву в одній хромосомі з подальшим поворотом сегмента, що утворився, на $180^{\circ}$. Залежно від розташування центромери, інверсії поділяють на пери- (із залученням центромери) та парацентричні (без залучення центромери).
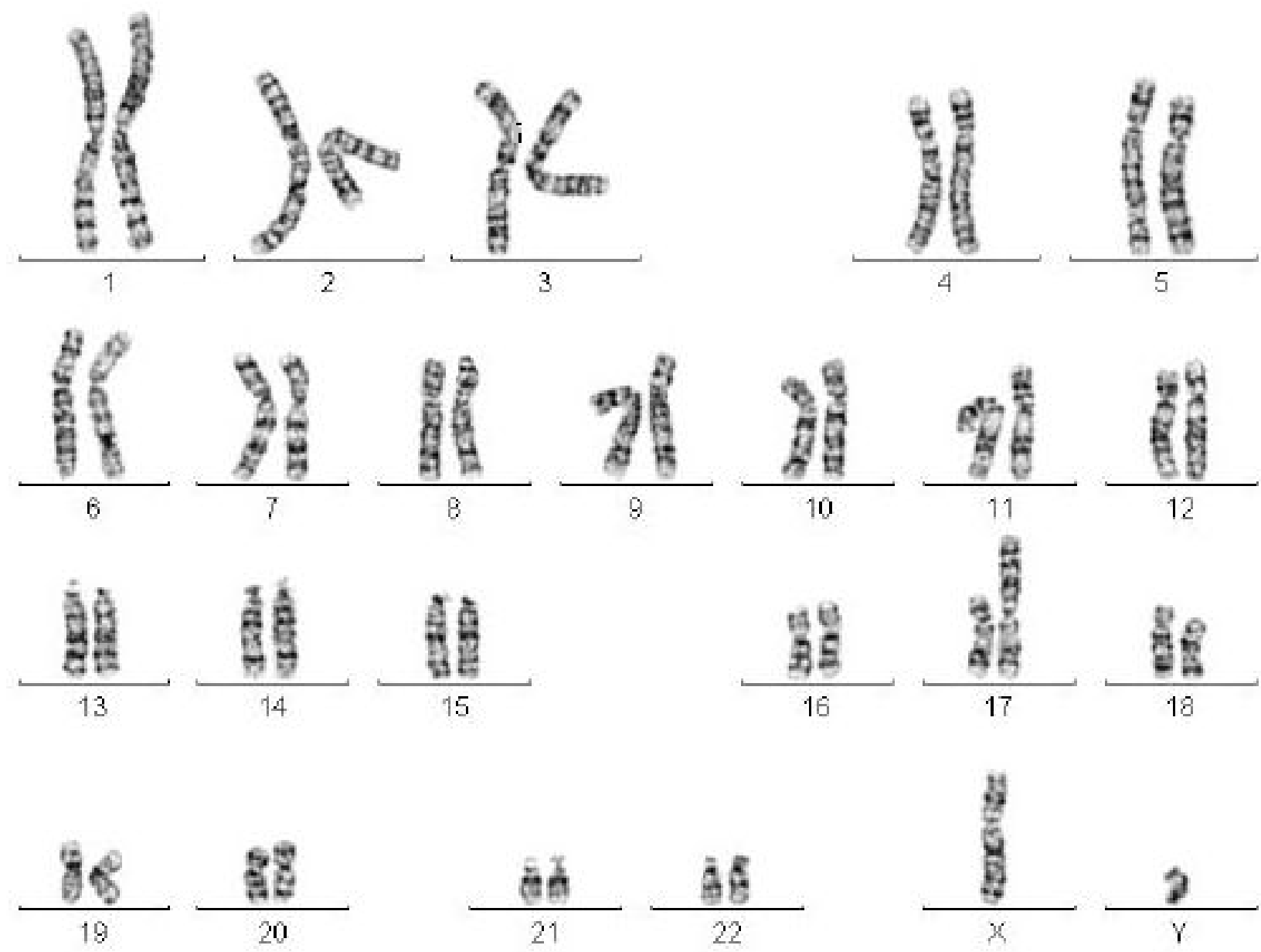

Рис. 3. Каріотип паціснта з реципрокною транслокацією між хромосомами 2 та 17 із точками розриву та сполучення в районах q31 та p13-46, XY, t(2;17)(q31;p13) 
Реципрокні транслокації, виявлені у паціснтів із безпліддям

\begin{tabular}{|c|l|l|}
\hline \multicolumn{1}{|c|}{ Кo } & \multicolumn{1}{|c|}{ Каріотип } & \multicolumn{1}{|c|}{ Фенотипічний прояв } \\
\hline 1 & $46, \mathrm{XY}, \mathrm{t}(1 ; 5)(\mathrm{p} 13 ; \mathrm{q} 11.2)$ & астенотератозооспермія \\
\hline 2 & $46, \mathrm{XY}, \mathrm{t}(1 ; 10)(\mathrm{p} 36.1 ; \mathrm{p} 11.2)$ & астенотератозооспермія \\
\hline 3 & $46, \mathrm{XY}, \mathrm{t}(2 ; 15)(\mathrm{q} 21.2 ; \mathrm{q} 25)$ & олігоастенотератозооспермія \\
\hline 4 & $46, \mathrm{XY}, \mathrm{t}(2 ; 17)(\mathrm{q} 31 ; \mathrm{p} 13)$ & олігоастенотератозооспермія \\
\hline 5 & $46, \mathrm{XY}, \mathrm{t}(2 ; 18)(\mathrm{p} 10 ; \mathrm{q} 10)$ & олігоастенозооспермія \\
\hline 6 & $46, \mathrm{XY}, \mathrm{t}(3 ; 8)(\mathrm{q} 13.2 ; \mathrm{p} 23.1)$ & олігоастенотератозооспермія \\
\hline 7 & $46, \mathrm{XY}, \mathrm{t}(13 ; 17)(\mathrm{q} 11.1 \mathrm{p} 13)$ & олігоастенотератозооспермія \\
\hline 8 & $45, \mathrm{XY}, \mathrm{t}(5 ; 15)(\mathrm{q} 35 ; \mathrm{q} 11),-15$ & олігоастенотератозооспермія \\
\hline 9 & $46, \mathrm{XY}, \mathrm{t}(5 ; 19)(\mathrm{p} 13 ; \mathrm{q} 13.1)$ & астенотератозооспермія \\
\hline 10 & $46, \mathrm{XY}, \mathrm{t}(5 ; 19)(\mathrm{q} 11.1 ; \mathrm{q} 12)$ & астенотератозооспермія \\
\hline 11 & $46, \mathrm{XY}, \mathrm{t}(6 ; 7)(\mathrm{q} 12 ; \mathrm{p} 15)$ & олігоастенотератозооспермія \\
\hline 12 & $46, \mathrm{XY}, \mathrm{t}(6 ; 13)(\mathrm{q} 25.1 ; \mathrm{q} 21.2)$ & олігоастенотератозооспермія \\
\hline 13 & $46, \mathrm{XY}, \mathrm{t}(6 ; 14)(\mathrm{p} 12 ; \mathrm{q} 31)$ & астенотератозооспермія \\
\hline 14 & $46, \mathrm{XY}, \mathrm{t}(9 ; 13)(\mathrm{p} 10 ; \mathrm{p} 12)$ & азооспермія \\
\hline 15 & $46, \mathrm{XY}, \mathrm{t}(9 ; 13)(\mathrm{q} 11 ; \mathrm{p} 11)$ & олігоастенозооспермія \\
\hline 16 & $46, \mathrm{XY}, \mathrm{t}(9 ; 15)(\mathrm{q} 32 ; \mathrm{p} 11.2)$ & астенотератозооспермія \\
\hline 17 & $46, \mathrm{XY}, \mathrm{t}(9 ; 16)(\mathrm{q} 22 ; \mathrm{p} 11)$ & астенотератозооспермія \\
\hline 18 & $46, \mathrm{XY}, \mathrm{t}(10 ; 19)(\mathrm{p} 14 ; \mathrm{p} 12)$ & олігоастенотератозооспермія \\
\hline 19 & $46, \mathrm{XY}, \mathrm{t}(15 ; 22)(\mathrm{q} 24 ; \mathrm{q} 13)$ & олігоастенотератозооспермія \\
\hline
\end{tabular}

У досліджуваній групі частота інверсій склала 0,6\%. Інверсії виявляють із частотою $0,022 \%$ у новонароджених (Nielsen and Wohlert, 1991), 0,088\% у донорів сперми (Ravel et al., 2006). У мейозі інвертовані хромосоми утворюють петлю, розмір якої залежить від величини інвертованого сегмента. Кросинговер між ділянками петлі викликає утворення незбалансованих гамет із дуплікаціями або делеціями сегментів, дистальних до інвертованих районів. Частота утворення незбалансованих гамет корелює із розміром інвертованого сегмента та коливається від 0,2 до 29\% (Perrin et al., 2009). Деякі 3 інверсій асоційовані з безпліддям та порушенням сперматогенезу, однак більшість із них не мають фенотипічного прояву (Mau-Holzmann, 2005; Chantot-Bastaraud et al., 2007). У досліджуваній групі в одного пацієнта 3 інверсією inv(10)(p12q21) не було виявлено жодних відхилень у показниках спермограми, три інші пацієнти характеризувались астенозооспермією.

Аналіз частот кількісних і структурних перебудов у підгрупах пацієнтів залежно від ступеня тяжкості порушення сперматогенезу виявив достовірне $(P<0,001)$ підвищення частоти кількісних аномалій у пацієнтів 3 азооспермією. Наші результати узгоджуються 3 попередніми даними про те, що кількісні аномалії гоносом частіше виявляють у пацієнтів з азооспермією, у той час як структурні перебудови реєструють, в основному, у пацієнтів 3 оліго- та астенозооспермією (Elghezal et al., 2006; Rao et al., 2006; Vijayalakshmi et al., 2011).

У пацієнтів із відхиленнями показників спермограми частота хромосомних аномалій вища, ніж у загальній популяції. У досліджуваній групі загальна частота хромосомних аномалій склала 6,6\%. За даними мета-аналізу результатів каріотипування 3087 пацієнтів із безпліддям, середня частота хромосомних аномалій у групі чоловіків iз відхиленнями показників спермограми складає 7,7\% (Martin, 2008) та перевищує популяційну в 10-12 разів (Nielsen and Wohlert, 1991). Частота хромосомних аномалій у пацієнтів із безпліддям варіює у межах 3-19\% і залежить від критеріїв включення пацієнтів у дослідження та співвідношення підгруп пацієнтів із різним ступенем тяжкості порушення сперматогенезу (Rao et al., 2005; Bertini et al., 2006; Chantot-Bastaraud et al., 2008; Kumtepe et al., 2009; Alkalaf and Al-Shoumer, 2010; Dul et al., 2010; Hofherr et al., 2011). Найнижчу частоту хромосомних аномалій у пацієнтів із безпліддям виявлено Dul et al. (2012) у групі з 1223 пацієнтів із безпліддям (3,1\%), у яку було включено пацієнтів із нормозооспермією та невдалими попередніми спробами ДРТ. Вищу частоту (19-23\%) хромосомних аномалій зареєстровано у дослідженнях чоловіків із тяжкими формами порушення сперматогенезу: олігозооспермією та азооспермією (Baschat et al., 1996; Kleiman et al., 1999; Foresta et al., 2005). Нами виявлено підвищення частоти хромосомних аномалій зі зростанням відхилень показників спермограми - від 1,1\% у підгрупі пацієнтів із нормозооспермією до 11,6\% у підгрупі з олігоастенотератозооспермією та 35,0\% у підгрупі із азооспермією (рис. 4).

Серед пацієнтів із відсутністю відхилень показників спермограми виявлено лише одну хромосомну аномалію перицентричну інверсію хромосоми 10 inv(10)(p12q21). Частота хромосомних аномалій у пацієнтів без відхилень у показниках спермограми, наприклад, донорів сперми, становить 0,37\% (Ravel et al., 2006) і майже не відрізняється від частоти у новонароджених (Nielsen and Wohlert, 1991). Тобто значна частка збалансованих хромосомних перебудов, які не порушують сперматогенез, залишається не діагностованою. Однак навіть за відсутності фенотипічного прояву носії збалансованих перебудов мають підвищений ризик утворення гамет із незбалансованим набором та, відповідно, безпліддя, невиношування або народження дітей із хромосомною патологією. Тому частота хромосомних аномалій у пацієнтів із нормозооспермією та безпліддям в анамнезі $є$ дещо вищою і складає 2,0-2,6\% (Gekas et al., 2001; Yatsenko et al., 2010).

У пацієнтів з астенозоо- та астенотератозооспермією не виявлено підвищення частоти хромосомних аномалій. Наші дані узгоджуються 3 результатами інших дослідників (Clementini et al., 2005; Dul et al., 2012) та свідчать, що пацієнти зі зниженою рухливістю сперматозоїдів, а також зниженою рухливістю та відхиленнями морфоло- 
гічних показників сперматозоїдів не належать до групи ризику виявлення хромосомних аномалій.

Частота хромосомних аномалій достовірно зростає зі зниженням концентрації сперматозоїдів: у групах пацієнтів з олігоастенозооспермією, олігоастенотератозооспермією та азооспермією виявлено достовірне підвищення частоти хромосомних аномалій (табл. 2).

За літературними даними, частота хромосомних аномалій у групах пацієнтів 3 азооспермією коливається в межах 11-24\% (Elghezal at al., 2006; Wang et al., 2010), а у пацієнтів з олігозооспермією - в межах 2-16\% (Ferlin et al., 2005; Martin, 2008; Yatsenko et al., 2010). Висока частота хромосомних аномалій у пацієнтів з азооспермі$\epsilon ю(35,0 \%)$ та олігозооспермією (10,3\%) у нашому дослідженні зумовлена особливостями групи пацієнтів: частина 3 них були направлені до Клініки репродуктивної медицини «Надія» для проведення ПГД у зв'язку з невдалими попередніми спробами ДРТ або самовільними викиднями в анамнезі.

Для визначення критичної концентрації сперматозоїдів, за якої зростає ризик виявлення хромосомних аномалій, вважали за доцільне розділити пацієнтів з олігозооспермією на тяжку олігозооспермію (концентрація сперматозоїдів $\leq 5 \times 10^{6} \mathrm{мл}^{-1}$ ) та помірну олігозоспермію (концентрація сперматозоїдів $>5 \times 10^{6} \mathrm{мл}^{-1}$ ). Виявлено достовірне підвищення частоти хромосомних аномалій у пацієнтів із тяжкою олігозооспермією $(P<0,05)$ та азооспермією $(P<0,0001)$ порівняно з нормальною концентрацією сперматозоїдів.

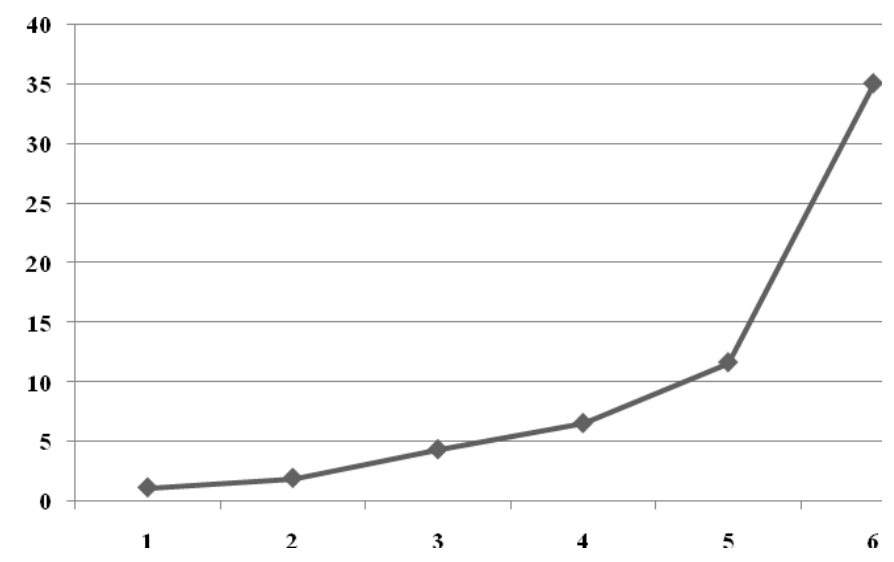

Рис. 4. Частота хромосомних аномалій у підгрупах паціснтів із різним ступенем порушення сперматогенезу: 1 - нормозооспермією, 2 - астенозооспермією, 3 - астенотератозооспермією, 4 - олігоастенозооспермією, 5 - олігоастенотератозооспермією, 6 - азооспермією

Частота типів хромосомних аномалій у паціснтів залежно від тяжкості порушення сперматогенезу

\begin{tabular}{|l|c|c|c|c|}
\hline \multicolumn{1}{|c|}{ Тип порушення } & $\begin{array}{c}\text { Кількість } \\
\text { пацієнті }\end{array}$ & $\begin{array}{c}\text { Частота кількісних } \\
\text { хромосомних аномалій, \% }\end{array}$ & $\begin{array}{c}\text { Частота структурних } \\
\text { хромосомних аномалій, \% }\end{array}$ & $\begin{array}{c}\text { Загальна частота } \\
\text { хромосомних аномалій, \% }\end{array}$ \\
\hline Нормозооспермія & 87 & 0 & 1,1 & 1,1 \\
\hline Астенозооспермія & 156 & 0,6 & 1,3 & 1,9 \\
\hline Астенотератозооспермія & 257 & 0,4 & 3,9 & 4,3 \\
\hline Олігостенозооспермія & 46 & 2,2 & 4,3 & $6,5^{*}$ \\
\hline Олігоастенотератозооспермія & 138 & 0,7 & 10,9 & $11,6^{*}$ \\
\hline Азооспермія & 40 & 25 & 10 & $35^{*}$ \\
\hline
\end{tabular}

Примітка: * $-P \leq 0,05$.

Частота хромосомних аномалій у паціснтів із різною концентрацією сперматозоїдів

\begin{tabular}{|l|c|c|c|c|c|c|}
\hline $\begin{array}{c}\text { Концентрація спер- } \\
\text { матозоїдів, мл }^{-1}\end{array}$ & $\begin{array}{c}\text { Кількість } \\
\text { пацієнтів }\end{array}$ & $\begin{array}{c}\text { Кількість пацієнтів із } \\
\text { хромосомними аномаліями }\end{array}$ & $\begin{array}{c}\text { Частота хромосомних } \\
\text { аномалій }\end{array}$ & OR & СI & $P$ \\
\hline$>15 \times 10^{6}$ & 500 & 15 & 3,0 & - & - & - \\
\hline $5-15 \times 10^{6}$ & 80 & 7 & 8,8 & 3,1 & $1,22-7,86$ & $<0,01$ \\
\hline$<5 \times 10^{6}$ & 104 & 12 & $11,5^{*}$ & 4,21 & $1,91-9,30$ & $<0,001$ \\
\hline Азооспермія & 40 & 14 & $35,0^{* *}$ & 17,41 & $7,60-39,86$ & $<0,001$ \\
\hline
\end{tabular}

Примітки: * $-P<0,05, * *-P<0,001$.

Рекомендації щодо дослідження каріотипу чоловіків 3 олігозооспермією базуються на тому, що чоловіки зі зниженою концентрацією сперматозоїдів мають підвищений ризик хромосомних аномалій. Так, ризик виявлення хромосомних аномалій зростає у групі пацієнтів із помірною олігозооспермією у 3,1 раза, із тяжкою олігозооспермією - у 4,2 раза, з азооспермією - у 17,4 раза. Тобто зниження концентрації сперматозоїдів $є$ інформа- тивним критерієм для селекції пацієнтів із підвищеним ризиком хромосомних аномалій.

\section{Висновки}

Установлено підвищену частоту кількісних і структурних перебудов хромосом у лімфоцитах периферичної 
крові чоловіків із відхиленнями показників спермограми, які проходили лікування безпліддя з використанням методів ДРТ. Частота хромосомних аномалій зростала зі зниженням концентрації сперматозоїдів і була найвищою в осіб з олігозооспермією та азооспермією, що вказує на необхідність дослідження каріотипу у таких пацієнтів перед проведенням циклів ДРТ.

\section{Бібліографічні посилання}

Alkhalaf, M., Al-Shoumer, K., 2010. Cytogenetic abnormalities and azoospermia factor (AZF) microdeletions in infertile men from Kuwait. Journal of Molecular and Genetic Medicine 4, 232-234.

AUA and ASRM: American Urological Association and American Society for Reproductive Medicine, 2006. Report on optimal evaluation of the infertile male. Fertility and Sterility 86, 202-209.

Baschat, A.A., Kupker, W., al Hasani, S., Diedrich, K., Schwinger, E., 1996. Results of cytogenetic analysis in men with severe subfertility prior to intracytoplasmic sperm injection. Human Reproduction 11, 330-333.

Bertini, V., Simi, P., Valetto, A., 2006. Cytogenetic study of 435 subfertile men: Incidence and clinical features. Journal of Reproductive Medicine 51, 15-20.

Blanco, J., Egozcue, J., Vidal, F., 2001. Meiotic behavior of sex chromosomes in three patients with sex chromosome anomalies $(47, \mathrm{XXY}$, mosaic $46, \mathrm{XY} / 47, \mathrm{XXY}$ and $47, \mathrm{XYY})$ assessed by fluorescence in situ hybridization. Human Reproduction 16, 887-892.

Chantot-Bastaraud, S., Ravel, S., Siffroi, J.P., 2008. Underlying karyotype abnormalities in IVF/ICSI patients. Reproductive Biomedicine Online 16, 514-522.

De Kretser, D.M., 1997. Male infertility. Lancet 349, 787-790.

Dul, E.C., Groen, H., van Ravenswaaij-Arts, C.M.A., Dijkhuizen, T., van Echten-Arends, J., Land, J.A., 2012. The prevalence of chromosomal abnormalities in subgroups of infertile men. Human Reproduction 27, 36-43.

Dul, E.C., van Ravenswaaji-Arts, C.M., Groen, H., van EchtenArends, J., Land, J.A., 2010. Who should be screened for chromosomal abnormalities before ICSI treatment? Human Reproduction 25, 2673-2677.

Eaker, S., Pyle, A., Cobb, J., Handel, M.A., 2001. Evidence of meiotic spindle checkpoint from analysis of spermatocytes from Robertsonian-chromosome heterozygous mice. Journal of Cell Science 114, 2953-2965.

Elghezal, H., Hidar, S., Braham, R., Denguezli, W., Ajina, M., Saad, A., 2006. Chromosome abnormalities in one thousand infertile males with nonobstructive sperm disorders. Fertility and Sterility 86, 1792-1795.

Escudero, T., Abdelhadi, I., Sandalinas, M., Munne, S., 2003. Predictive value of sperm fluorescence in situ analysis on the outcome of preimplantation genetic diagnosis for translocations. Fertility and Sterility 79, 1528-1534.

Ferlin, A., Garolla, A., Foresta, C., 2005. Chromosome abnormalities in sperm of individuals with constitutional sex chromosomal abnormalities. Cytogenetics and Genome Research 111, 310-316.

Foresta, C., Garolla, A., Bartoloni, L., Bettella, A., Ferlin, A., 2005. Genetic abnormalities among severely oligospermic men who are candidates for intracytoplasmic sperm injection. Journal of Clinical Endocrinology and Metabolism 90, $152-156$

Gekas, J., Thépot, F., Turleau, C., Siffroi, J.P., Dadoune, J.P., Briault, S., Rio, M., Bourrouillou, G., Carre-Pigeon, F., Wasels, R., Benzacken, B., 2001. Chromosomal factors of infertility in candidate couples for ICSI: An equal risk of con- stitutional aberrations in women and men. Human Reproduction 16, 82-90.

Georgiou, I., Syrrou, M., Pardalidis, N., Karakitsios, K., 2006. Genetic and epigenetic risks of intracytoplasmic sperm injection method. Asian Journal of Andrology 8, 643-673.

Giwersman, A., Tournay, H., Diemer, T., 2012. European Association of Urology Guidelines on Male Infertility: The 2012 Update. European Urology 62, 324-332.

Harton, G.L., Tempest, G., 2012. Chromosomal disorders and male infertility. Asian Journal of Andrology 14, 32-39.

Hoffher, S.E., Wiktor, A.E., Kipp, B.R., Dawson, D.B., Van Dyke, D.L., 2011. Clinical diagnostic testing for the cytogenetic and molecular causes of male infertility: The Mayo Clinic experience. Journal of Assisted Reproduction and Genetics 12, 1-8.

Huynh, T., Mollard, R., Trounson, A., 2002. Selected genetic factors associated with male infertility. Human Reproduction Update 8, 183-198.

Kleiman, S.E., Yogev, L., Gamzu, R., Hauser, R., Botchan, A., Lessing, J.B., 1999. Genetic evaluation of infertile men. Human Reproduction 14, 33-38.

Kruger, T.F., Menkyeld, R., Stander, F.S., Lombard, C.J., Van der Merwe, J.P., van Zyl, J.A., Smith, K., 1986. Sperm morphologic features as a prognostic factor in in vitro fertilization. Fertility and Sterility 46, 1118-1123.

Kumtepe, E., Beyazyurek, C., Cinar, C., Ozbey, I., Oskan, S., Cetinkaya, K., Karlikaya, G., Karagozoglu, H., Kahraman, S., 2009. A genetic survey of 1935 Turkish men with severe male factor infertility. Reproductive Biomedicine Online 18, 465-474.

Lanfranco, F., Kamischke, A., Zitzmann, M., Nieschlag, E., 2004. Klinefelter's syndrome. Lancet 364, 273-283.

Lipshultz, L.I., Lamb, D.J., 2007. Risk of transmission of genetic diseases by assisted reproduction. Nature Clinical Practice Urology 4, 460-466.

Maiburg, M., Repping, S., Giltay, J., 2012. The genetic origin of Klinefelter syndrome and its effect on spermatogenesis. Fertility and Sterility 98, 253-260.

Martin, R.H., 2008. Cytogenetic determinants of male fertility. Human Reproduction Update 14, 379-390.

Mau-Holzamann, U.A., 2005. Somatic chromosomal abnormalities in infertile men and women. Cytogenetic and Genome Research 111,317-336.

Mroz, K., Hassold, T.J., Hunt, P.A., 1999. Meiotic aneuploidy in the XXY mouse: Evidence that a compromised testicular environment increases the incidence of meiotic errors. $\mathrm{Hu}-$ man Reproduction 14, 1151-1156.

NICE: National Institute for Clinical Excellence, 2004. Fertility: Assessment and Treatment for People with Fertility Problems. London, RCOG Press.

Nielsen, J., Wohlert, M., 1991. Chromosome abnormalities found among 34910 newborn children: Results from a 13year incidence study in Arhus, Denmark. Human Genetics 87, 81-83.

Oates, R.D., 2012. The natural history of endocrine function and spermatogenesis in Klinefelter syndrome: What the data show. Fertility and Sterility 98, 266-273.

O'Flynn O'Brien, K.L., Varghese, A.C., Agarwal, A., 2010. The genetic causes of male factor infertility: A review. Fertility and Sterility $93,1-12$.

Perrin, A., Caer, E., Oliver-Bonet, M., Navarro, J., Benet, J., Amice, V., de Braekeleer, M., Morel, F., 2009. DNA fragmentation and meiotic segregation in sperm of carriers of a chromosomal structural abnormality. Fertility and Sterility 92, 583-589.

Rao, K.L., Babu, K.A., Kanakavalli, M.K., Padmalatha, V.V., Deenadayal, M., Singh, L., 2005. Prevalence of chromosome defects in azoospermic and oligoasthenoteratozoospermic South Indian infertile men attending an in- 
fertility clinic. Reproductive Biomedicine Online 10, 467 472.

Reynolds, N., Cooke, H.J., 2005. Role of the DAZ genes in male fertility. Reproductive Biomedicine Online 10, 72-80.

Schiff, J.D., Palermo, G.D., Veeck, L.L., Goldstein, M., Rosenwaks, Z., Schlege, P.N., 2005. Success of testicular sperm extraction and intracytoplasmic sperm injection in men with Klinefelter syndrome. Journal of Clinical Endocrinology and Metabolism 90, 6263-6267.

Shaffer, L.G., Slovak, L.M., Campbell, L.G., 2009. ISCN 2009: An International System for Human Cytogenetic Nomenclature. Karger.

Stephenson, M., Sierra, S., 2006. Reproductive outcomes in recurrent pregnancy loss associated with a parental carrier of a structural chromosome rearrangement. Human Reproduction 21, 1076-1082.

Vijayalakshmi, J., Venkatchalam, P., Paul, S., Rani, G., Kymarasamy, P., Kannan, J., 2011. Chromosomal anomalies in patients with azoospermia and oligoasthenoteratozoospermia. International Journal of Human Genetics 11, 117-121.

Wang, R.X., Fu, C., Yang, Y.P., Han, R.R., Dong, Y., Dai, R.L., Liu, R.Z., 2010. Male infertility in China: Laboratory finding for AZF microdeletions and chromosomal abnormalities in infertile men from Northeastern China. Journal of assisted Reproduction and Genetics 27, 391-396.

WHO. World Health Organization, 2010. Laboratory Manual for the Examination and Processing of Human Semen. Geneva.

Yatsenko, A.N., Yatsenko, S.A., Weedin, J.W., Lawrence, A.E., Patel, A., Peacock, S., Matzuk, M.M., Lamd, D.J., Cheung, S.W., Lipshultz, L.I., 2010. Comprehensive 5-year study of cytogenetic abberations in 668 infertile men. Journal of Urology 183, 1636-1642.

Yoshida, A., Miura, K., Shirai, M., 1997. Cytogenetic survey of 1,007 infertile males. Urologia Internationalis 58, 166-176.

Надійшла до редколегії 21.02.2013 